\title{
ПРЕБОЛУВАњЕТО НА ТРАУМАТА ВО „КНИГАТА НА ИЛУЗИИТЕ“ ОД ПОЛ ОСТЕР
}

\author{
Васко Талевски \\ Центар за странски јазици „Филос”, Скопје \\ talevskivasko@yahoo.com
}

\begin{abstract}
„Книгата на илузиите“, едно од најпознатите дела на Пол Остер, е метафизички роман во кој повеќето од ликовите доживуваат некаков вид траума. Овој труд ги обработува прашањата како главните ликови на романот се соочуваат, излегуваат накрај и дали ја преболуваат траумата во своите животи. Дејвид Зимер и Хектор Ман се ликовите низ кои ке ја вршиме психоанализата. Потоа, преку нив ќе ги објасниме психолошките алатки и методи што ќе ни помогнат да ги разбереме концептите на живот и на смрт, не само во литературата туку и во вистинскиот свет. Психолошките концепти на Зигмунд Фројд ќе бидат објаснети и применети на ликовите и во специфични ситуации за да сфатиме како луѓето излегуваат накрај со траумата. Исто така, во ова истражување ќе се зборува за концептите на меланхолија и тагување, архивот, ид, его и суперего, ерос и танатос, кои ќе бидат објаснети со специфични примери од романот и од други дела. Меѓутоа, треба да се истакне дека траумата, како што е дефинирана од психолозите, не е нешто што може да се заборави и да се избрише, туку нешто што останува во психата и помага за да се изгради „карактерот“ на една личност, што се потврдува и со самиот роман.
\end{abstract}

Клучни зборови: траума, тагување, меланхолија, архив, илузии 


\title{
OVERCOMING TRAUMA IN THE BOOK OF ILLUSIONS BY PAUL AUSTER
}

\author{
Vasko Talevski \\ Center for Foreign Languages Philos, Skopje \\ talevskivasko@yahoo.com
}

The Book of Illusions, one of Paul Auster's most famous novels, is a metaphysical work where most of the characters undergo a traumatic experience. This research analyses the psyche of the characters. It deals with the grieving process, specifically how the characters deal with and face their traumas, and whether they overcome them. Moreover, this psychoanalytic study focuses on the main protagonists, David Zimmer and Hector Mann, who serve as examples through which the concepts of life and death are examined. The concept of trauma is approached and analysed through the work of many psychoanalysts, especially Sigmund Freud's work and research, which helps explain how people deal with trauma. Additionally, the psychoanalysis of this research examines the concepts of melancholia, grief, the archive, id, ego and superego, as well as the concepts of Eros and Thanatos, which are analysed with specific examples from the novel and other works. However, it has to be said that trauma as defined by psychoanalysts, is not something that can be forgotten or erased, but something that dwells in the psyche and helps form a person's character, which is exactly what Paul Auster proves in his novel, The Book of Illusions.

Key words: trauma, grief, melancholia, the archive, illusions 


\section{1 Вовед}

Во овој труд преку главните ликови на романот ќе биде илустрирано како човекот што доживеал огромна траума во својот живот излегува накрај со меланхолијата што го обзема и го води неговиот живот; како една личност варира меѓу концептите на ерос и танатос и која е улогата што ја имаат меморијата, егото, суперегото и ид во психата на човекот; потоа, како субјектот како „архив“" излегува накрај со таа траума, кој и каков е процесот на жалење и меланхолија.

Во романот Книг̄aӣa на илузиийе (2002) преовладуваат темите на депресија и смрт, за кои ќе стане збор подоцна во овој труд. Во метафиктивниот свет на Остер главниот лик се појавува како писател што раскажува за трагедиите што му се случиле и за тоа како тој се обидувал да најде смисла во својот живот. Дејвид Зимер е професор по компаративна книжевност, чие семејство, како што се дознава во романот, умира во авионска несреќа. Овој настан е на некој начин почетокот и срцевината на дејството во делото, настан што ќе ни даде субјект за психоанализа во однос на тоа како еден човек излегува накрај со траумата во животот. Во процесот на жалење по семејството, го гледаме Зимер во ризична психичка состојба, со самоубиствени мисли и под дејство на алкохол, но, кога ќе помислиме дека за нашиот протагонист нема надеж во животот, се појавува пресвртница во форма на комеgија, нем филм од дваесеттите во кој главна улога има вториот главен лик и,во случајов, вториот субјект за психоанализа, Хектор Ман, кој со својата визуелна комедија успева да пламне некоја искра живот во Зимер. Хектор Ман, слично како Зимер, има тежок живот. Неговата кариера е загрозена со доаѓањето на звукой во филмовите. Покрај ова, во животот на Хектор се случуваат голем број трагични настани што ќе го следат овој лик на патот на самосожалување и меланхолија и од чија сенка тој нема да може да излезе до крајот на својот живот. Животите на овие два лика се слични, испреплетени со тага и со траума, и со тоа тие ќе послужат како одлични субјекти за психоанализа во ова истражување.

Како што спомнавме претходно, концептот на „архивот“ “ке биде присутен во ова истражување. Јонатан Боултер во својата книга Меланхолијай $а$

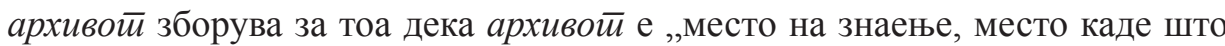
самата историја е вдомена, каде што минатото е сместено“ (Boulter 2011: 3). ${ }^{1}$ Личностите што претрпеле некаква траума во своето минато самите

\footnotetext{
1 Освен ако не е инаку наведено, сите цитати се во превод на авторот на трудот.
} 
стануваат место на архивирање. Тие служат како субјекти што сами ја архивираат тагата во своите животи. Архивите го одржуваат минатото во живот. Па, така, на некој начин, главните ликови на овој роман самите ќе послужат како архиви на своите животи, на своите трауми.

Според Фројд, постојат два начина на кои човекот реагира на траумата -

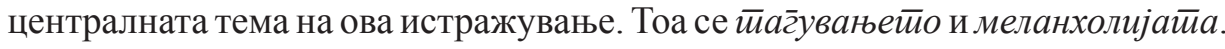
Овие два процеса се разликуваат еден од друг. Тагувањето е процес при кој изгубеното се сфаќа и се прифаќа; тагувањето е нормален начин низ кој една личност мора да излезе накрај со траумата и со загубата... (Boulter 2011: 5). Од друга страна, „меланхолијата“ е ,,абнормална реакција кон загубеното и го става субјектот во постојана позиција на нарциситичка идентификација со загубениот објект“ (Boulter 2011: 5). Истото ова ќе може се согледа преку главните ликови на делото на Остер, кои на сопствен начин ќе ги доживеат овие две фази на жалење.

Значајни поими што ќе помогнат во сфаќањето на психата на двата главни лика се противречните концепти на ерос и йанайос. Еросот, како што го објаснува Фројд (Freud 2003) во книгата 3ag иринцийой на заgоволсииво, е „сексуалниот нагон, кој е далеку повпечатлив и попристапен за нашето знаење и разбирање. Тој го содржи не само отворениот сексуален нагон... туку и самоодржувачкиот нагон, кој се припишува на егото...“ (Freud 2003: 220). Од друга страна, танатос, грчкиот збор за смрт, е „деструктивниот нагон - кој произлегува од омразата - и стои зад високиот смртен нагон“ (Freud 2003: 223).

Уште еден концепт што исто така ќе помогне во ова истражување и што му се припишува на Фројд се концептите на $u g$, ег̃o и суйерег̄o, кои исто така помагаат во разбирањето на човечката психа. Како што вели Фројд, „Егото го претставува тоа што може да се нарече разум, во контраст со ид, кој ги содржи страстите“ (Freud 2003: 201-202). Суперегото, од друга страна, ,...владее над егото како негова свест и како потсвесно чувство на вина“" (Freud 2003: 213).

По објаснувањето на психолошките концепти потребни за сфаќање на ликовите, а и на самиот роман, може да се премине на главниот дел од истражувањето - преболувањето на траумата низ ликовите на Книг̄ā̄a на илузиитее. Оваа анализа ќе биде поделена на два дела зашто начинот на излегување накрај со траумата кај двата лика е различен. Тоа го потврдува и Дебра Шостак, која во трудот Во земјайа на исчезнайи луѓе: наращија на ираумайа кај Пол Остиер пишува:

Најважната разлика...во Книг̄aйа на илузиийе е начинот на кој главните ликови реагираат на траумата. Хектор Ман се предава на меланхоличниот нихилизам на преживувачката тага, додека Зимер се соочува со загубата со зачудувачка стабилност. (Shostak 2009: 12) 
Исто така, ќе бидат дадени уште неколку примери од ликовите на романот, чии животи се исто така исполнети со трауматични случки.

\section{2 Дејвид Зимер}

„Она што ни се случило никогаш не е изгубено“ (Auster 2002). Книг̄айа на илузииие има едноставен правец. Го следиме животот на Дејвид Зимер, поточно како Зимер се соочува со загубата на своето семејство. Тука почнува приказната, психоанализата што ќе помогне при сфаќањето на процесот наречен йраума. „На седми јуни 1985 година, по само една недела од нашата десетгодишнина, мојата жена и двајцата синови умираат во авионска несреќа“" (Auster 2002: 10). Ова е почетокот на трауматичната траекторија што ќе го изгради каракӣероӣ на главниот јунак и ќе послужи како лекција во светот со излегување накрај со траумата. На почетокот, како и кај секоја незгода, трауматичното дејство ја носи личноста во надолна линија, во депресија. Оваа депресија е особено изразена кога личноста што ја претрпела траумата лично себеси се обвинува за несреќата.

Најлошо од сѐ беше моето инсистирање да ги возам до Бостон за да фатат директен лет. Не сакав да тргнат од Бурлингтон. Тоа би значело дека треба да тргнат од Њујорк на авион со пропелер со осумнаесет седишта само за да фатат друг лет за Милвоки и ѝ кажав на Хелен дека не ги сакам тие мали авиони. Преопасни се, реков, и не можев да ја поднесам помислата да ја пуштам заедно со децата на еден од нив без мене. И не заминаа - само за јас да не берам гајле. Тие заминаа на поголем авион, а најлошото беше што јас ги избрзав да се качат на него. (Auster 2002: 11-12)

Ова самообвинување и преземање на вината имаат големи психички последици и предизвикуваат меланхолија, која, како што тврди Фројд и како што е објаснета во делото на Боултер, е погрешниот начин на излегување накрај со траумата. Токму ова се случува во почетните фази на тагувањето кај Зимер по неговото семејство. Честа придружна појава кај меланхоличарот, во овој случај Зимер, е алкохолот. Како и повеќето луѓе што се обидуваат да ги убијат своите маки во алкохол, така и протагонистот на ова дело се обидува да најде утеха во алкохолот. Како што вели Зимер:

Зедов отсуство од работа за зимскиот семестар, но, наместо да одам да побарам психолошка помош, останав дома и продолжив да тонам. До крајот на септември или почетокот на октомври, пиев повеќе од половина шише виски секоја вечер. Ме држеше да не чувствувам многу, но во исто време 
ме лиши од каква било смисла за иднината, а кога човек нема за што да се радува, може да речеме дека е мртов. (Auster 2002: 13)

Ова чувство на безнадежност е тоа што ги води луѓето во депресија и со што се одликува меланхолијата. Исто така, оваа безизлезна ситуација ги води луѓето кон самоубиство, за што ќе стане збор понатаму во овој труд.

Уште едно обележје на меланхолијата е тоа што личноста не може да се оттргне од саканите што ги изгубила или од работите што ја потсетуваат на нив: „меланхоличарот не може да прифати дека неговата љубов веќе jа нема...“ (Boulter2011: 5). Ова придонесува кон продлабочување на меланхолијата и е токму тоа што се случува со Зимер.

Кога не бев пијан или испружен на софата во дневната соба додека гледав телевизија, го поминував времето шетајќи низ куќата. Ќе ги посетев собите на своите деца и ќе седнев на подот, опкружен со нивните работи. (Auster 2002: 12)

Оваа меланхоличност кај Зимер ќе продолжи некое време и, токму кога читателот помислува дека за главниот лик нема спас, дека ќе тоне сѐ подлабоко, се случува нешто неверојатно, пресвртница во животот на Зимер и во заплетот на делото, што ќе укаже на тоа како еден човек може да ги преброди меланхолијата и траумата и да излезе на крај со нив. Зимер се присетува на овој момент што ќе го смени неговиот живот на подобро:

Така стоеја работите кога Хектор Ман неочекувано влезе во мојот живот. Немав поим кој е, никогаш не сум го ни сретнал неговото име, но една вечер баш пред почетокот на зимата, кога дрвјата конечно се оголија и првиот снег само што не беше паднал, случајно видов снимка од еден од неговите стари филмови на телевизија, и ме насмеа. (Auster 2002: 14)

Тука станува јасно дека сепак постојат надеж и спас за Зимер, пат надвор од оваа меланхоличност. Дури и самиот Зимер, свесен за оваа промена, вели: „Штом можев да се насмеам, тоа значи дека не сум целосно умртвен“ (Auster 2002: 14). И тука, во целата оваа безизлезност, се гледаме како трауматичната траекторија на Зимер почнува да се менува, да зема правец нагоре, кон подобро, кон излез што на крајот ќе направи од него личност што ќе може да живее и да излезе накрај со болката.

Опседнат со ликот на Хектор, Зимер одлучува да не ги поминува своите денови во алкохол и во самосожалување, туку да се фатиза работа и да напише биографија за животот и делото на Хектор, кое ќе послужи како огледало на душата на Хектор. Добро е познато дека работата ја ублажува болката или барем за кратко ги трга мислите од тагата. Истото ова го потврдува Шостак 
во својот труд, каде што пишува за тоа дека ликовите од делото, со тоа што наоѓаат нова цел и работа во своите животи, се впуштаат во терапевтски процес што ги доближува до прифаќањето на загубата. Значајно е да се каже дека ова истражување ќе го прати Зимер на вистинската патека на заздравување и неговата меланхолија ќе се претвори во „тагување“, кое, како

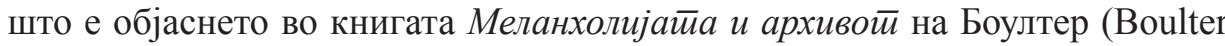
2011), е вистинскиот начин на преболување. Оваа нова работа за кратко ќе му даде цел на животот на Зимер.,Не се прашував дали сето ова вреди да се прави. Ја имав својата работа и единственото нешто што беше важно беше да продолжам и да ја завршам работата“" (Auster 2002: 24). Исто така, во процесот на оваа нова работа, пишувањето на биографијата на Хектор, Зимер конечно, а и првпат по авионската несреќа во која загинале неговата жена и деца, ќе треба да се соочи со своите стравови. За да го заврши своето истражување, Зимер ќе треба да патува со авион, нешто што речиси ќе го натера да се откаже од истражувањето. Но понатаму во романот се дознава дека со помош на апчиња за спиење Зимер успева да се соочи со своите стравови и да го реализира ова патување. Ова соочување со сопствените стравови ќе биде од огромно значење за психата и за здравјето на Зимер, кој по успешното патување вели: „Утрото на деветти јануари се разбудив во непознат кревет и тоа беше моментот кога мојот живот повторно почна“ (Auster 2002: 31).

Набргу по завршувањето на биографијата на Хектор, може да се забележи како полека, но сигурно, меланхолијата се враќа кај Зимер. Дури и краткиот период на неработа е доволен да го остави човека со неговите мисли, кои во случајот на Зимер се мрачни и опасни за неговиот живот. Но, за негова среќа, набргу наоѓа нова работа, нова цел, која исто така ќе биде од голема помош и ќе го тргне од неговите трауматични сеќавања. Зимер ќе почне со преведување на биографијата на Шатобријан.

Понатаму во романот, за време на преведувањето, Зимер е поканет од пријатели како гостин на нивна забава. Оваа ситуација, исто така, ќе биде новост во неговиот живот по авионската несреќа, со тоа што првпат ќе треба да се дружи со група луѓе, што е различно од неговиот сегашен самотен живот и претставува нов страв со кој ќе треба да се соочи. Оваа средба нема да помине добро, може да се забележи како Зимер ги изгубил своите друштвени способности со тоа што ќе се кара за време на забавата:

Не беше ништо страшно, но премногу испив за да го знам тоа, и кога ги видов своите маслосани панталони и својата измачкана кошула, решив да се навредам. Не се сеќавам што реков, но беше нешто лошо и навредливо, нешто што можеше да остане неречено. Несмасна краво. Мислам дека тоа беше. Но, може да беше и глупава краво, или глупава несмасна краво. (Auster 2002: 75) 
Ова е одличен пример за тоа како траумата може да влијае врз една личност и да ја онеспособи да функционира во вистинскиот свет.

Но можеби најважниот момент за Зимер и за романот во целина е некаде кон крајот, кога ќе се вкрстат патиштата на Зимер и на Алма Грунд. Алма Грунд е ќерката на камерманот на Хектор, кој ги снимил повеќето негови филмови и кој заедно со своето семејство живее во соседството на Хектор и на неговата сопруга Фрида Спелинг. Како што се дознава од разговорите меѓу Зимер и Алма, таа, исто така, пишува книга за животот и делото на Хектор и на некој начин доаѓ кај Зимер за да го убеди да дојде во Тиера дел Суено, каде што живее Хектор. Ова препирање и убедување се од големо значење затоа што преку нив ќе ги сфатиме животните погони во човечката психа, т.е. односот помеѓу еросот и танатосот. Алма, доведена во мат-ситуација, се заканува дека ќе го убие Зимер со пиштол ако тој не дојде со неа кај Хектор. Но тоа што Алма не го сфаќа е дека Зимер, на некој начин, веќе има умрено. Дел од Зимер умира заедно со неговото семејство во таа авионска несреќа и тој самиот е свесен за тоа, колку и да негира: „Јас бев само некој што се преправаше дека е жив, мртовец што ги минуваше своите денови во превод на книга од мртов човек“" (Auster 2002: 104). Така, сега, по оваа негова мрачна тајна и исповед, станува јасно она што тој ѝ го вели на Алма: „Ајде, пукај, ѝ реков. Ке ми направиш услуга“ (Auster 2002: 110). На самиот крај од расправијата, пак, Зимер ѝ го зема пиштолот на Алма и се заканува со самоубиство: „Го зедов пиштолот од неа, се тргнав неколку чекори и си го вперив во глава““ (Auster 2002: 112). Оваа драматична ситуација, стравот од смртта, ја доведува Алма во солзи, а Зимер доживува епифанија и различно сфаќање на целата ситуација. Како

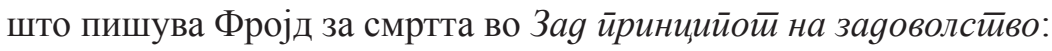

Има само едно можно објаснување за стравот од смртта што се јавува во меланхолијата, тоа дека егото се предава зашто мисли дека е мразено и прогонувано од суперегото, наместо да е сакано од него. (Freud 2003: 244)

Еросот Фројд го објаснува како „сексуален нагон, кој е далеку повпечатлив и попристапен за нашето знаење и разбирање. Тој ги содржи не само отворениот сексуален нагон... туку и самоодржувачкиот нагон што се припишува на егото..." (Freud 2003: 220). Зимер повторно се вљубува и тука неговото заздравување достигнува крешендо: „,...ја држев во прегратки и ја бакнував“" (Auster 2002: 118). Згора на тоа, Зимер конечно повторно постанува емотивен и вели: „...й кажав дека изгледа прекрасно“ (Auster 2002: 120). Оваа нова љубов го прави Зимер нов, прероден човек, кој сега полн со самодоверба се впушта во нови авантури и многу полесно се соочува со своите стравови. Фројд го потврдува ова влијание на љубовта 
кога во својата книга пишува: „кога се вљубуваме, се реактивираат сите детинести сништа за моќ и задоволство (Freud 2003: 20). Се чини дека е Зимер на крајот од своето тагување, како што потврдува и Боултер, кој пишува: „Тој го повлекува своето либидо од изгубениот предмет - неговата жена и деца - и го пренасочува другаде: кон филмовите на Хектор, кон Алма, со која почнал страсна љубовна афера“ (Вoulter 2011: 30). Меѓутоа, на имотот на Хектор на Зимер му се случуваат низа непријатни работи. Прво, по кратка средба и разговор со Зимер, Хектор умира и неговата жена, Фрида, поттикната од минат договор со Хектор, одлучува да ги уништи филмовите на својот маж. Но најголемата загуба што му се случува на Зимер, покрај уништувањето на филмовите, е смртта на Алма, која, бесна поради целата ситуација, случајно ја бутка и ја убива Фрида. Неможејќи да го поднесе ова, Алма се самоубива. И тука, на крајот, при обраќњето на Зимер кон читателот, „драг читателу“, станува јасно дека главниот лик на делото на Остер, и покрај сите овие работи, излегува како нова и цврста личност, со нов карактер, кој, изграден и обликуван од траумите во неговиот живот, прави да може да преброди нова смрт и да може да живее со себе, со своите мисли и со сето она што му се случило во животот. Ова мислење го потврдува Боултер, кој вели дека: „Неговото тагување ја зема формата на живот и, на некој начин, ова е невообичаен метод на тагување: тој ја повлекува својата либидна поврзаност со изгубениот предмет, Алма, и ја поврзува со својот живот“ (Boulter 2011: 32). Зимер ќе продолжи да живее и по смртта на Алма, а доказ за тоа е „Книгата на илузиите“. И затоа може да се каже дека Зимер успеал успешно да ја преброди траумата, а тоа зашто успеал да ја сфати. Истиов заклучок го има во делото Зайамейување на иянинай $а$ на Сара Клифт, во кое е изложен заклучокот на францускиот филозоф Бланшо за загубата, минатото и сегашноста: „за да се доведе загубата докрај, човек треба да ја знае и да го знае нејзиниот досег; мора да тагува вистински и да ја претстави тагата како облик или предмет на знаење“" (Clift 2014: 174).

\section{3 Хектор Ман}

„Така стоеја работите кога Хектор Ман неочекувано влезе во мојот живот“ (Auster 2002: 14). Како што Хектор влегол во животот на Зимер така ние сега ќе влеземе во животот на Хектор за да ја сфатиме и да ја анализираме неговата траума. Како што беше споменато погоре во анализата на Зимер, Хектор е холивудски актер што глумел во ерата на немите филмови. Тоа што Хектор успеал да го направи, да ги разбуди страста и желбата за живот кај еден гледач, е токму тоа што ни овозможува да влеземе во неговиот живот и да ја видиме неговата кратка филмска кариера: 
Веќе до 1932 или 1933 година, Хектор припаѓаше на еден изумрен свет, а и да имаше некои траги од него, тоа беше само некоја фуснота во непозната книга, која никој веќе не се заморуваше да ја чита. Филмовите зборуваа сега, а трепкавите неми филмови веќе беа заборавени. (Auster 2002: 7)

Овој копнеж по минатото, а и желбата за смеа и за живот, е тоа што ќе го натера Зимер да напише биографија за Хектор и да го обелодени неговиот живот, кој, како што може да се забележи, е ист, ако не и потрауматичен од неговиот. Преку истражувањето на Зимер се дознава дека Хектор потекнува од семејство на полски Евреи мигранти, кои преку Аргентина дошле во Њујорк. Хектор сакал да се пробие на филмската сцена во Холивуд со тоа што глумел во неми филмови, кои му овозможувале да го скрие својот тежок шпански нагласок. Но, со доаѓањето на звуците во филмовите, кариерата на Хектор е загрозена и, за да не го открие јавноста, тој одеднаш одлучува да ја прекине својата кариера и да избега не само од филмската сцена туку и општо од јавниот живот: „Круг се затвора околу неговото лице и е голтнат од темнината. Миг подоцна, за прв и последен пат во неговите филмови, зборовите КРАЈ се напишани на екранот и тоа е последен пат некој да го види“ (Auster 2002: 57). Меѓутоа, при читањето на „Книгата на илузиите“, се дознава дека тоа не била единствената причина за исчезнувањето на Хектор. Тука влегуваме во неговите мрачни тајни, кои ќe ги доловат најмрачните длабочини на меланхолијата. Симболичниот пиштол не означува промена само во животот на Зимер туку и во животот на Хектор. Се дознава дека Хектор се гледал со две жени во исто време и тука настанува првиот значаен конфликт, кој ќе остане врежан и ќе го демне до крајот на неговиот живот. Животот на Хектор станува трауматичен кога Бриџит О'Фалон, жената со која има афера и ја забременува, решава да се соочи со Долорес, жената со која Хектор треба да се ожени. Во оваа конфронтација, Долорес, случајно, во самоодбрана, ја застрелува и ја убива Бриџит: „О'Фалон тропна на вратата на Долорес и, дур' Хектор да ја заврши својата работа и да се врати назад, Долорес случајно ја застрелува О'Фалон во левото око со куршум со калибар триесет и два““ (Auster 2002: 139). Од овој момент натаму, животот на Хектор оди во надолна линија. Не само што е прв сведок на ова убиство, за кое може да се каже и дека самиот е виновен, туку и, за да го прикрие сето ова, самиот ја закопува кутрата Бриџит. Хектор не одлучува да се соочи со своите стравови, туку бега од нив, а токму тоа ќе биде најголемиот товар во неговиот живот. Неговиот процес на тагување преминува во меланхолија, која го наоѓa своето место во овој контекст токму онака како што е опишана од Фројд:

Ако првично се препуштиме на меланхолијата, дознаваме дека пресилното суперего, кое веќе ја презело контролата над свеста, го напаѓа егото со 
невидена бруталност, како за своите цели да го има собрано целиот садизам присутен во таа личност. За да го протолкуваме садизмот, ќе кажеме дека деструктивниот дел се припоил кон суперегото и се свртил против егото...и често успева да го доведе егото до негова смрт, а ако егото не успее навреме да го одбие овој угнетувач, преминува во манија. (Freud 2003: 237)

Може да се каже дека животот на Хектор е совршено опишан со ова објаснување на меланхолијата и на садизмот од страна на Фројд. Хектор ќе премине во длабоко депресивна, небаре манијакална состојба, која може да се забележи не само во неговите подоцнежни обиди за самоубиство туку и во неговите крајно болни и садистички дела на искупување.

Првото нешто што Хектор го прави е тоа што го менува своето име. Мисли дека со ова менување на својот идентитет ќе го заборави и ќе го отфрли својот минат живот. Новото име, доста иронично, го опишува животот што го има и што допрва доаѓа: „Херман Лесер/Лузер. Некои ќе го изговараат Лесер, а некои ке го читаат како Лузер. Во секој случај, Хектор го најде името што го заслужува“" (Auster 2002: 146). Во превод од англиски, lesser е помал, како потчинет или нечиј поданик, a loser - губитник. Тука почнува неговото искупување. Хектор се преселува во родниот град на О’Фалон, наоѓ работа во продавницата на нејзиното семејство, се спријателува со нив и на извитоперен садистички начин се вљубува во Нора, сестрата на Бриџит:

Немаше да биде толку страшно да не ја сакаше многу, ако длабоко во себе не се вљубеше уште првиот пат кога се видоа“ (Auster 2002: 165). Но, на крајот, Хектор ја сфаќа изопаченоста на целата ситуација и одлучува повторно да бега. Како што се дознава преку Алма: „Се обидел да се убие во Монтана наредниот ден, рече Алма, и три дена подоцна повторно пробал во Чикаго. (Auster 2002: 177)

Ова е тој екстремен вид меланхолија, кога личноста ќе го допре самото дно на депресијата и ќе се обиде да си го одземе животот или, како што го нарекува Фројд, деструктивниот нагон, кој „поаѓа од омразата - и го претставува несфатливиот смртен нагон“ (Freud 2003: 223). Во ваквите случаи на меланхолија „чувството на вина е екстремно свесно; суперегото покажува особена суровост во таквите случаи и го напаѓа егото на најнемилосрден начин“ (Freud 2003: 234). Овој негов вид искупување, преку нанесување болка и самосожалување, ќе продолжи кога Хектор ќе сретне проститутка, која ќе го убеди да оформат секс-дуо „Бони и Клајд“: „Има мажи, рече, богати мажи во Чикаго, богати мажи насекаде низ средишниот дел на Америка, кои се спремни да потрошат огромни пари за да гледаат луѓе како се ебат“ (Auster 2002: 180). Оваа негова деградација 
ќe трае неколку месеци, кога конечно ќе сфати дека и ова самопонижување нема да го искупи. Ова константно самопонижување е очигледен повик за казна, казна за сето она што го направил во својот живот. Хектор повторно исчезнува за дејството во романот да нѐ доведе до една банка, каде што неговиот живот ќe добие пресвртница, доза адреналин што ќе го врати од мртвите.

Во банката Хектор не само што спречува грабеж туку и ја среќава и ја спасува љубовта на својот живот, Фрида Спелинг. Фрида ќе го препознае вистинскиот Хектор, ќе се вљуби и ќе го промени неговиот живот. Тие ќе се венчаат, а Хектор, во понатамошен обид целосно да ги изгуби својот стар идентитет и живот, го зема презимето Спелинг. Семејството Спелинг ќе добие и дете и, кога сѐ ќе изгледа дека е совршено, дека Хектор конечно се искупил и нашол цел во својот живот, нивното дете умира. Трагичниот херој никако да излезе од бездната на траумата, која како сенка го следи и го прогонува низ животот. Хектор е повторно скршен, бездушен, но овој пат има некого покрај себе, некој што ќе му помогне да излезе накрај со оваа траума. Фрида ќе го натера Хектор повторно да снима филмови и тука тој ќе ја најде својата утеха. Ова ќе овозможува да се согледа концептот на „архивот“. Архивот е симболичното место каде што се зачувува меморијата, меморијата што ни дава увид во животите на ликовите од ова дело. Тоа е „воскреснување на приватното минато на еден човек, но исто така и впуштање во минатото на другите, со други зборови: историја“ (Shostack 2009: 6). Трауматичната историја на Хектор ќе биде архивирана во неговите

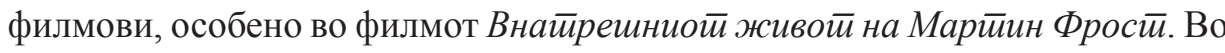
овој филм, кој е јасна реплика на животот на Хектор, Мартин ќе се откаже и ќе ја уништи својата уметност за да ја спаси својата љубена, Клер. Но ова е бесцелно. Мартин, исто како Хектор, живее во заблуда дека ќе може да ја спаси љубената и да го врати минатото со тоа што ќе ја уништи својата уметност. Ова е пример на пропаднато и неисполнето тагување. Како што потврдува Шостак: „Делото на Мартин го одекнува тоа на Хектор; тој може само да се залажува дека ја повратил својата љубов со тоа што се повлекол во тишина, а всушност се испразнил себеси од страст" (Shostack 2009: 13). Овој филм ги рефлектира животите на Хектор и на Зимер, но тој, исто така, многу лесно и ги потсетува на нивното минато, кое само ги враќа во меланхолија. Иако читателот може да види само еден од подоцнежните филмови на Хектор, тој, како и другите, ги означува работата и обидот на Хектор да излезе накрај со своето минато. Колку и да го враќаат и да го потсетуваат на болките од неговото минато, тие му дозволуваат на Хектор да се доближи до нив, да ги сфати и до одреден степен да ги прифати тие трауми. Работата, како кај Зимер така и кај Хектор, успева да ги научи да живеат заедно со траумата. Во случајот на Хектор, доказ е долгиот живот 
што тој го има пред да умре, но многу значаен за сфаќање на неговата траума е самиот крај на трудот, кога Хектор го поканува Зимер да биде сведок на неговите таинствени исповедни филмови. Хектор длабоко во себе знае дека, за да го оствари своето тагување, треба да има сведок, човек со слично минато, кој би можел да го сфати неговиот трауматичен живот. Истово го потврдува Боултер кога вели:

Филмовите се толку длабоко исполнети со вина што дури и бараат да бидат видени од барем една друга личност, Дејвид Зимер: вината, со други зборови, бара сведок; тагувањето бара сведок за да успее, за да се истера докрај. (Boulter 2011: 28)

\section{4 Заклучок}

„Ако и кога оваа книга ќе биде објавена, драг читателу, може да бидете сигурни дека човекот што ја напишал е одамна мртов“ (Auster 2002: 317). Како што може да се забележи во самиот крај, покрај Хектор, мртов е и Зимер, протагонистот и писателот на ова дело. Нивните животи, колку и да се трагични и жалосни, служат како доказ, како архива, која се надеваме дека ќе им послужи на сите што ќе го читаат ова дело да сфатат што е тоа траума и како може човек да излезе накрај со неа. Хектор и Зимер со своите трауми служат како примери дека траумата останува како архив на минатото и како таква служи како искуство што не само што ги зајакнува главните ликови на ова дело туку и ги подготвува да се соочат со животот. Оваа анализа служи како пример за тоа како се излегува накрај со траумата и кои се последиците ако не се прифати или ако се игнорира. Доказ се протагонистите, кои со своите дела само потврдуваат дека, каква и да е траумата, подобро е да се прифати, да се сфати и да се работи на и со неа, отколку да се игнорира и да се бега од неа. Ова е единствениот начин да се преброди тагата. Како што на Хектор му требал сведок за да го заврши своето тагување така му требал и на Зимер, а тоа сме ние, читателите на ова дело. Нашиот став е дека и Зимер и Хектор умираат среќни со тоа што знаат дека нивната болка и тага нема да бидат заборавени, тука ќе има сведоци што ќе ја видат и ќе ја искусат нивната тага. Кога тагата ќе биде просведочена, кога веќе не е само некоја тајна меморија, таа е прежалена. Насловот Книг̄айа на илузиийе е соодветен затоа што ова е книга на илузии, која навистина се обидува да го направи невозможното, да ја претвори болката во разбирлив јазик. 


\section{Библиографија}

Auster, P. (2002). The book of illusions. London: Faber \& Faber.

Boulter, J. (2011). Melancholy and the archive: Trauma, history and memory in the contemporary novel. London: Continuum International Publishing Group.

Clift, Sr. (2014). Committing the future to memory: History, experience, trauma. New York: Fordham University Press.

Freud, S. (2003). Beyond the pleasure principle and other writings. London: Penguin Books Ltd.

Shostak, D. (2009). In the country of missing persons: Paul Auster's narratives of trauma. Studies in the Novel, 41 (1): 66-87. 